\title{
Methyl Mercaptan Oxidase, a Key Enzyme in the Metabolism of Methylated Sulphur Compounds by Hyphomicrobium EG
}

\author{
By G. M. H. SUYLEN, ${ }^{1 *}$ P. J. LARGE, ${ }^{2}$ J.P. VAN DIJKEN ${ }^{1}$ AND \\ J. G. KUENEN ${ }^{1}$ \\ ${ }^{1}$ Department of Microbiology and Enzymology, Delft University of Technology, Julianalaan $67^{A}$, \\ 2628 BC Delft, The Netherlands \\ ${ }^{2}$ Department of Biochemistry, The University of Hull, Hull HU6 $7 R X, U K$
}

(Received 27 February 1987; revised 5 June 1987)

\begin{abstract}
Methyl mercaptan (MM)-oxidase was purified tenfold to near homogeneity from Hyphomicrobium $\mathrm{EG}$ grown on dimethyl sulphoxide. The enzyme was a monomer with an $M_{\mathrm{r}}$ value of about 40000-50000. It catalysed the formation of stoicheiometric amounts of formaldehyde, sulphide and $\mathrm{H}_{2} \mathrm{O}_{2}$ from $\mathrm{MM}$ and $\mathrm{O}_{2}$. It had a $K_{\mathrm{m}}$ of 5-10 $\mu \mathrm{M}$ for $\mathrm{MM}$ and was strongly inhibited by substrate concentrations above $14 \mu \mathrm{M}$, the $K_{\mathrm{i}}$ for this inhibition being $42 \mu \mathrm{M}$. Ethyl mercaptan and sulphide also served as substrates for the enzyme ( $K_{\mathrm{m}} 18$ and $60 \mu \mathrm{M}$ respectively), whereas methanol was not oxidized. Upon oxidation of these compounds $\mathrm{H}_{2} \mathrm{O}_{2}$ was formed. Although sulphide was a substrate for the enzyme, it also acted as a non-competitive inhibitor of MM oxidation $\left(K_{\mathrm{i}} 90 \mu \mathrm{M}\right)$. Alcohol oxidase (EC 1.1.3.13) purified from Hansenula polymorpha was also found to oxidize $\mathrm{MM}\left(K_{\mathrm{m}} 110 \mu \mathrm{M}\right)$ although at a low rate. The products formed were the same as for MM oxidation by the bacterial enzyme. In contrast to MM-oxidase however, alcohol oxidase was inactive with sulphide and was not inhibited by methyl mercaptan concentrations up to $500 \mu \mathrm{M}$.
\end{abstract}

\section{INTRODUCTION}

Recently, the physiology of Hyphomicrobium EG and Hyphomicrobium S, bacteria which can grow well on dimethyl sulphide (DMS) and dimethyl sulphoxide (DMSO), has been studied in detail (de Bont et al., 1981; Suylen \& Kuenen, 1986; Suylen et al., 1986). It appeared that during growth on either of these compounds Hyphomicrobium EG was using the methyl groups as a carbon and energy source, but the sulphur moiety could serve as an extra energy source (Suylen $e t$ al., 1986). During growth of Hyphomicrobium spp. on DMS or DMSO, methyl mercaptan (MM) appeared to be a metabolic intermediate (de Bont et al., 1981; Suylen \& Kuenen, 1986; Suylen et al., 1986). Since in vitro studies revealed that MM was only oxidized under aerobic conditions and no coenzyme was required for this reaction (de Bont et al., 1981; Suylen \& Kuenen, 1986; Suylen et al., 1986), it seemed likely that an oxidase was catalysing the oxidation of MM. This was supported by the relatively high catalase activities found in DMS(O)-grown Hyphomicrobium EG compared to methylamine-grown cells, in which the metabolic pathway does not involve $\mathrm{H}_{2} \mathrm{O}_{2}$ production (Suylen et al., 1986). Furthermore, the catalase inhibitor 3-amino1,2,4-triazole (Cohen \& Somerson, 1969) proved to be lethal for Hyphomicrobium EG during growth on DMSO, whereas growth on methylamine was unaffected by it (Suylen et al., 1986).

Apart from its key role in the cleavage of a C-S bond during the metabolism of methylated sulphur compounds by Hyphomicrobium spp., MM-oxidase also was of particular interest

\footnotetext{
Abbreviations: DMS, dimethyl sulphide; MM, methyl mercaptan; ABTS, 2,2'-azino-bis-(3-ethylbenzthiazoline6-sulphonate); DMAB, 3-dimethylaminobenzoic acid; MBTH, 3-methyl-2-benzothiazolinone hydrazone; EM, ethyl mercaptan.
} 
because its substrate and three products are known to be very toxic. It was therefore anticipated that a study of the kinetics and the stoicheiometry of the reaction catalysed by this enzyme might explain some of the toxicity problems encountered during cultivation of these organisms on DMS(O). This paper reports the purification of MM-oxidase, establishes the products and the stoicheiometry of the reaction catalysed, gives some characteristics of the enzyme and describes several methods for assaying its activity.

\section{METHODS}

Media and culture conditions. Hyphomicrobium EG, Delft culture collection number LMD 84.101, was grown in a Chemap fermenter with a working volume of 101 in a mineral salts medium under DMSO (30 mM) limitation as described previously (Suylen et al., 1986), except that the amount of trace elements and magnesium and ammonium salts in the medium was doubled. The dilution rate $(D)$ was $0.018 \mathrm{~h}^{-1}$, the temperature $30^{\circ} \mathrm{C}$, the $\mathrm{pH}$ was maintained at 7.0 by automatic titration with $2 \mathrm{M}-\mathrm{NaOH}$ and the dissolved $\mathrm{O}_{2}$ concentration was kept at $50 \%$ of air saturation.

Chemicals. DEAE-Sephacel was obtained from Merck, Sephacryl S-300 from Sigma, and hydroxylapatite (BioGel HT) from Bio-Rad. $M_{\mathrm{r}}$ standard proteins were obtained from Sigma. Peroxidase and 2,2'azino-bis-(3ethylbenzthiazoline-6-sulphonate) (ABTS) were from Boehringer. 3-Methyl-2-benzothiazolinone hydrazone (MBTH) and 3-dimethylaminobenzoic acid (DMAB) were from Janssen Chimica. All other chemicals used were of analytical grade.

Purification of MM-oxidase. Cells were harvested and washed twice with $50 \mathrm{~mm}$-Tris/ $\mathrm{HCl} \mathrm{pH} 8.2$ by centrifugation for $20 \mathrm{~min}$ at $22500 \mathrm{~g}$ at $4{ }^{\circ} \mathrm{C}$. Approximately $15 \mathrm{~g}$ wet wt of cells was suspended in $30 \mathrm{ml} 10 \mathrm{~mm}$ Tris/ $\mathrm{HCl} \mathrm{pH} 8.2$ and disrupted by passing 4-6 times through a French pressure cell at $110 \mathrm{MPa}$. The crude cellfree extract was obtained by centrifugation for $20 \mathrm{~min}$ at $40000 \mathrm{~g}$ at $4{ }^{\circ} \mathrm{C}$. It was loaded on to a DEAE-Sephacel column $(20 \times 2.5 \mathrm{~cm})$ equilibrated with $10 \mathrm{mM}-\mathrm{Tris} / \mathrm{HCl} \mathrm{pH} 8.2$ and the column was washed with the same buffer. The enzyme was eluted with a linear gradient of $10-250 \mathrm{~mm}$-potassium chloride in $280 \mathrm{ml} 10 \mathrm{~mm}$-Tris/ $\mathrm{HCl} \mathrm{pH} 8 \cdot 2$. The peak of activity emerged at a chloride concentration of approximately $55 \mathrm{mM}$. Fractions containing more than $50 \%$ of the maximum specific activity were combined and dialysed against 1 litre $3 \mathrm{~mm}$-potassium phosphate $\mathrm{pH} 7.5$ for $3 \mathrm{~h}$. The material was then applied to a hydroxylapatite (Bio-Gel HT) column $(10 \times 1 \mathrm{~cm})$ equilibrated with $3 \mathrm{mM}$-potassium phosphate $\mathrm{pH} 7 \cdot 5$. After washing with the same buffer the column was eluted with a linear gradient of 3-150 mM-potassium phosphate $\mathrm{pH} 7.5$ in $200 \mathrm{ml}$. The peak of enzyme activity was at approximately $20 \mathrm{mM}$ phosphate.

$M_{r}$ determinations and purity check. The $M_{\mathrm{r}}$ of the enzyme was determined by gel permeation chromatography on a Sephacryl S-300 column. The subunit $M_{\mathrm{r}}$ was determined by SDS-PAGE as described by Weber \& Osborn (1969). Purity of the enzyme was also assessed by gel permeation HPLC with dual wave length detection (205 and $280 \mathrm{~nm}$ ) as described by Frank et al. (1985), except that a Serva Si-300-polyol column was used.

Analytical procedures. Protein was determined by the method of Bradford (1976).

Enzyme assays. MM-oxidase activity can in principle be determined in five different ways, namely by following either the utilization of (i) $\mathrm{MM}$ or (ii) $\mathrm{O}_{2}$, or the formation of (iii) $\mathrm{H}_{2} \mathrm{O}_{2}$, (iv) formaldehyde or (v) sulphide. The (dis)appearance of these compounds (except for MM) was assayed continuously at $30^{\circ} \mathrm{C} . \mathrm{O}_{2}$ consumption was measured polarographically with a Clark-type oxygen electrode (Biological Oxygen Monitor, Yellow Springs Instrument $\mathrm{Co}$.), sulphide formation was followed at $254 \mathrm{~nm}$ (the molar absorption coefficient of sulphide at this wavelength is approximately $\left.14001 \mathrm{~mol}^{-1} \mathrm{~cm}^{-1}\right), \mathrm{H}_{2} \mathrm{O}_{2}$ production was measured at $590 \mathrm{~nm}$ via the oxidative coupling of MBTH and DMAB by peroxidase using the method of Ngo \& Lenhoff (1980) altered as indicated below, and formaldehyde production was measured in a coupled assay with formaldehyde dehydrogenase from Hansenula polymorpha especially purified for this purpose by the method of Kato et al. (1972). In view of the detection limit of the various methods, the latter method was routinely used for assaying MM-oxidase activity. The reaction mixture $(1.0 \mathrm{ml})$ contained : $50 \mathrm{mM}-\mathrm{Tris} / \mathrm{HCl} \mathrm{pH} 8.2 ; 1$ unit of formaldehyde dehydrogenase; $3 \mathrm{~mm}-\mathrm{GSH}$; $1 \mathrm{mM}-\mathrm{NAD}^{+}$and approximately $4 \mu \mathrm{g}$ purified enzyme. The reaction was started by the addition of $\mathrm{MM}$; in reference cuvettes formaldehyde dehydrogenase and $\mathrm{MM}$ were omitted. Rates are expressed in nmol $\mathrm{NAD}^{+}$ reduced $\min ^{-1}$ (mg protein) $)^{-1}$. MM solutions were prepared as described previously (Suylen et al., 1986).

Sulphide oxidation by the purified enzyme preparation was measured either by determining the oxygen consumption as described above or by following the sulphide disappearance using the method of Trüper \& Schlegel (1964) or by determining the decrease in absorbance at $254 \mathrm{~nm}$. In the first case the reaction mixture $(1.0 \mathrm{ml})$ contained $50 \mathrm{~mm}$-potassium phosphate buffer $\mathrm{pH} 7.5$ and about $8 \mu \mathrm{g}$ enzyme. Sulphide was added to a final concentration of $30 \mu \mathrm{M}$. Rates are expressed in $\mathrm{nmol} \mathrm{O}_{2} \mathrm{~min}^{-1}$ (mg protein) $)^{-1}$ and were corrected for endogenous $\mathrm{O}_{2}$ uptake. For the second determination, reaction mixtures were as above except that $0.1 \mathrm{mM}$ sulphide was added. The reaction was stopped after 2 or $3 \mathrm{~min}$ (depending on the activity of the preparation) by the addition of $2 \%$ zinc acetate according to Trüper \& Schlegel (1964). The rates are expressed in $\mathrm{nmol} \mathrm{S} \mathrm{S}^{2-} \mathrm{min}^{-1}$ 
(mg protein $)^{-1}$ and were corrected for auto-oxidation of sulphide measured in reaction mixtures without enzyme. For the third method, mixtures containing $50 \mathrm{~mm}$-potassium phosphate $\mathrm{pH} 7.5$ and about $70 \mu \mathrm{M}$-sulphide were made. After $5 \mathrm{~min}$ equilibration the reaction was started by adding about $8 \mu \mathrm{g}$ of the purified material per $\mathrm{ml}$. Formation of elemental sulphur could in principle be established using the latter procedure since the molar absorption coefficient of elemental sulphur is approximately seven times higher than that of sulphide at this wavelength. Also the method described by Sörbo (1957) was used in an attempt to establish the formation of elemental sulphur from sulphide by the enzyme.

Ethyl mercaptan (EM) oxidation by purified MM-oxidase was assayed by coupling with partially purified acetaldehyde dehydrogenase from $H$. polymorpha, which also appeared to be present in our formaldehyde dehydrogenase preparation from this micro-organism. Reaction mixtures were identical to those for $M$ oxidation except that EM was now added to start the reaction. Although GSH was not necessary for the reaction it was included in the reaction mixture since it appeared to increase the reaction rate slightly.

The MM-oxidase preparation was checked for peroxidative activity using the method with ABTS described by Verduyn et al. (1984), or the chromogenic assay described by Ngo \& Lenhoff (1980). The reaction mixtures contained about $8 \mu \mathrm{g}$ enzyme $\mathrm{ml}^{-1}$.

Catalase activity was measured spectrophotometrically at $240 \mathrm{~nm}$ as described by Haywood \& Large (1981) and calculated using the method described in the Sigma catalogue.

In all assays activity was linear with enzyme concentration.

Stoicheiometry measurements. To establish the stoicheiometry of the reaction, the reactants and products of MM oxidation were measured according to the following procedure. For each time interval and every compound, separate reaction mixtures $(1.0 \mathrm{ml})$ were made which contained: $50 \mathrm{~mm}$-Tris $/ \mathrm{HCl} \mathrm{pH} 8.2$, about $4 \mu \mathrm{g}$ purified enzyme and $80 \mu \mathrm{M}-\mathrm{MM}$. When formaldehyde was to be determined the reaction was stopped by the addition of $0.65 \%(\mathrm{w} / \mathrm{v})$ perchloric acid after which formaldehyde was measured according to Nash (1953). For the determination of sulphide the reaction was stopped by adding $0.23 \mathrm{M}-\mathrm{NaOH}$ and sulphide was measured as described by Trüper \& Schlegel (1964). For MM measurement the reaction was stopped by adding $1.7 \%(\mathrm{w} / \mathrm{v})$ acetic acid and the sulphide was removed by adding $0.022 \%(\mathrm{w} / \mathrm{v})$ zinc acetate, after which the precipitate was sedimented for $5 \mathrm{~min}$ in an Eppendorff centrifuge. After the mixture had been cooled in an ice-salt bath, $1 \mathrm{ml}$ supernatant was removed with a syringe through the lid of the Eppendorff tube to prevent MM losses and brought to $\mathrm{pH} 8 \cdot 1$ by adding $0 \cdot 23 \mathrm{M}-\mathrm{NaOH}$. After 3 min Ellman's reagent modified according to Kuwata et al. (1982) was added and MM was determined spectrophotometrically. In all cases the reaction mixtures were also cooled in an ice-salt bath to stop the reaction.

The stoicheiometry with $\mathrm{H}_{2} \mathrm{O}_{2}$ was determined at very low concentrations of $\mathrm{MM}$ using the peroxidase-coupled chromogenic assay as described by Ngo \& Lenhoff (1980), except that the assay was done in $50 \mathrm{mM}-\mathrm{Tris} / \mathrm{HCl}$ $\mathrm{pH} 8.2$ instead of in $100 \mathrm{~mm}$-sodium phosphate $\mathrm{pH} 6.5$. This was done because MM-oxidase has a relatively low activity at $\mathrm{pH} 6.5$ and in phosphate buffer. Although horse-radish peroxidase has a $\mathrm{pH}$ optimum of 6.5 , the amount used in the above method was sufficient for MM-oxidase to be the rate limiting enzyme of the coupled system. Freshly prepared solutions of MBTH and DMAB in $50 \mathrm{mM}-\mathrm{Tris} / \mathrm{HCl} \mathrm{pH} 8.2$ were used, since the compounds proved to be unstable at this $\mathrm{pH}$. Furthermore a lower molar absorption coefficient (about 40700) was found for the indamine dye at this $\mathrm{pH}$. In control experiments without peroxidase or without purified MM-oxidase no increase in absorbance at $590 \mathrm{~nm}$ was observed upon addition of MM.

Inhibition and substrate specificity of $M M$-oxidase. To test whether specific compounds could act as substrate for the enzyme, MM-oxidase was checked for its ability to catalyse $\mathrm{O}_{2}$ uptake in the presence of these compounds at concentrations varying from 0.1 to $1.0 \mathrm{~mm}$. In these tests elemental sulphur was added both as a sulphur sol in water as well as a saturated solution in acetone.

To establish the type of inhibition caused by several inhibitors the effect of varying their concentration at three fixed MM concentrations $(5,15$ and $100 \mu \mathrm{M})$ was studied in the formaldehyde dehydrogenase-coupled MMoxidase assay. The data obtained in these experiments were plotted according to Cornish-Bowden (1974) (s/v against inhibitor concentration).

\section{RESULTS}

\section{Purification and physical characteristics of MM-oxidase}

A typical purification procedure is shown in Table 1 . The ten times purified preparation obtained coeluted with horse-radish peroxidase on a Sephacryl S-300 column, indicating an $M_{\mathrm{r}}$ value of 40000-50000. On SDS-PAGE the enzyme proved to be nearly homogeneous with a subunit $M_{\mathrm{r}}$ of about 49000 . It had a pH optimum of 8.2 and could be stored for months at $-20^{\circ} \mathrm{C}$ without any apparent loss of activity. MM-oxidase resisted heating for $10 \mathrm{~min}$ at $50^{\circ} \mathrm{C}$, whereas a similar period at $65^{\circ} \mathrm{C}$ resulted in a complete loss of activity (see also Fig. 3). The 
Table 1. Purification of MM-oxidase

$\mathrm{MM}$-oxidase activity was determined at a final concentration of $100 \mu \mathrm{M}-\mathrm{MM}$, using the formaldehyde dehydrogenase-coupled assay.

$\begin{array}{lcccccc} & \begin{array}{c}\text { Total } \\ \text { Volume } \\ (\mathrm{ml})\end{array} & \begin{array}{c}\text { Total } \\ \left(\mu \mathrm{mol} \mathrm{min}^{-1}\right)\end{array} & \begin{array}{c}\text { protein } \\ (\mathrm{mg})\end{array} & \begin{array}{c}\text { Specific } \\ \text { activity } \\ {\left[\mu \mathrm{mol} \mathrm{min}^{-1}\right.} \\ \left(\mathrm{mg} \mathrm{protein}^{-1}\right]\end{array} & \begin{array}{c}\text { Purification } \\ \text { ratio }\end{array} & \begin{array}{c}\text { Yield } \\ (\%)\end{array} \\ \text { Crude extract } & 30 & 57.8 & 250 & 0.23 & 1 & 100 \\ \text { DEAE Sephacel } & 13 \cdot 7 & 33.9 & 59 & 0.57 & 2 \cdot 5 & 58 \\ \text { Hydroxylapatite } & 13.7 & 16 & 7.5 & 2 \cdot 13 & 9 \cdot 3 & 28\end{array}$

purified enzyme was colourless: its spectrum showed no absorbance in the visible region, but had some absorbance in the $300-400 \mathrm{~nm}$ region.

\section{Stoicheiometry of $M M$ oxidation}

If an oxidase was responsible for the oxidation of MM it seemed likely that it was catalysing the reaction according to equation 1 :

$$
\mathrm{CH}_{3} \mathrm{SH}+\mathrm{O}_{2}+\mathrm{H}_{2} \mathrm{O} \rightarrow \mathrm{HCHO}+\mathrm{H}_{2} \mathrm{~S}+\mathrm{H}_{2} \mathrm{O}_{2}
$$

The products and the stoicheiometry of the reaction were therefore investigated.

Upon oxidation of MM by the purified enzyme, stoicheiometric amounts of formaldehyde and sulphide were formed (Fig. 1). Within 2 min the MM-oxidizing activity declined to a very low level, probably due to a combination of substrate and product inhibition of the enzyme (see also Fig. $4 a$ and below).

From measurements with an oxygen electrode it was concluded that $0.5 \mathrm{~mol} \mathrm{O}_{2}$, rather than the expected $1.0 \mathrm{~mol}$, was consumed upon oxidation of $1.0 \mathrm{~mol}$ of $\mathrm{MM}$ (at a concentration of $50 \mu \mathrm{M}-\mathrm{MM}$ ), suggesting that the purified material still contained traces of catalase activity. Upon determining the catalase activity this indeed proved to be the case. Although only $0.02 \%$ of the total catalase activity of the crude extract was carried over in the purified enzyme preparation, this caused the latter to have a specific catalase activity of about $800-1000 \mathrm{nmol}$ $\mathrm{H}_{2} \mathrm{O}_{2} \min ^{-1}$ (mg protein $)^{-1}$, which was sufficient to affect the stoicheiometry measurements.

In establishing the stoicheiometry of the MM oxidation with respect to $\mathrm{H}_{2} \mathrm{O}_{2}$ formation in a coupled assay with added horse-radish peroxidase, the commonly used electron acceptors guiacol and ABTS proved useless since the coloured reaction products reacted with MM. Using the method of Ngo \& Lenhoff (1980) (see Methods) however, it became clear that at MM concentrations below $5 \mu \mathrm{M}$ the utilization of $1.0 \mathrm{~mol} \mathrm{MM}$ resulted in the production of $1.0 \mathrm{~mol}$ $\mathrm{H}_{2} \mathrm{O}_{2}$ (Fig. 2). At MM concentrations higher than about $5 \mu \mathrm{M}$ the coupled assay was no longer linear with the amount of MM added and the curve levelled off at a concentration of about $8 \mu \mathrm{M}$ $\mathrm{H}_{2} \mathrm{O}_{2}$. As shown below (Fig. $4 a$ ) this could not be due to MM-oxidase inhibition by MM, since this only occurred at MM concentrations above $14 \mu \mathrm{M}$. However, the presence of catalase in the purified material (see above) will greatly influence the outcome of this assay. Other complicating factors might be peroxidation of MM by the added peroxidase and/or inhibition of peroxidase (although added in excess) by MM. (Peroxidases are known to be inhibited by compounds containing thiol groups, Saunders et al., 1964.) MM did not react chemically with the indamine dye formed.

MM-oxidase itself showed no peroxidase activity with ABTS or the mixture of MBTH and DMAB used in the above assay. This indicated that MM oxidation in Hyphomicrobium EG is not by a peroxidase of the fungal type described by Paszczynski et al. (1985) to oxidize GSH and other thiol compounds with the formation of $\mathrm{H}_{2} \mathrm{O}_{2}$. It was concluded that $\mathrm{MM}$ oxidation did indeed proceed according to equation 1 .

\section{Sulphide oxidation by MM-oxidase}

The slow disappearance of sulphide after the initial build-up in the experiment shown in Fig. 1 suggested that MM-oxidase might have a sulphide-oxidizing capacity. In order to check this 


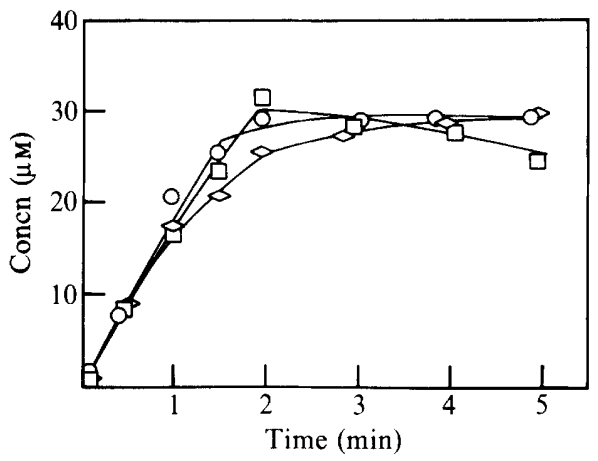

Fig. 1. Time-dependent formation of formaldehyde $(0)$ and sulphide $(\square)$ from MM by the purified MM-oxidase preparation. $O$, Amount of MM utilized. The concentration of the compounds was determined by the procedures described in Methods.

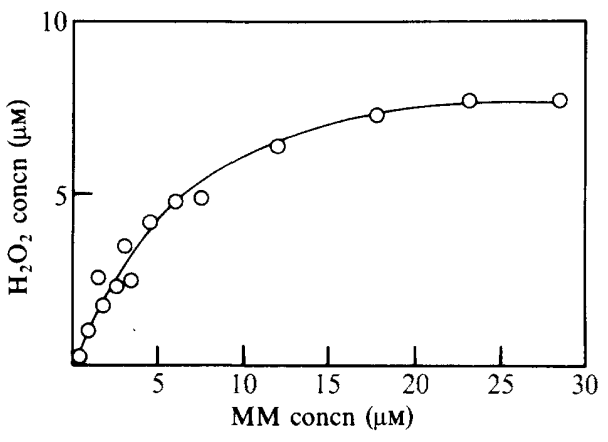

Fig. 2

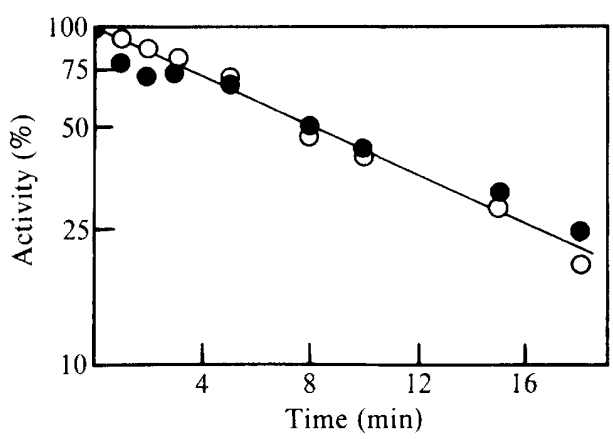

Fig. 3

Fig. 2. Dependence of $\mathrm{H}_{2} \mathrm{O}_{2}$ formation by $\mathrm{MM}$-oxidase on the $\mathrm{MM}$ concentration. $\mathrm{H}_{2} \mathrm{O}_{2}$ was measured using the peroxidase-coupled chromogenic assay of Ngo \& Lenhoff (1980).

Fig. 3. Time-dependent heat inactivation $\left(59^{\circ} \mathrm{C}\right)$ of $\mathrm{MM}$-oxidase $(\mathrm{O})$ and the sulphide oxidative capacity $(O)$ of the purified material from the hydroxylapatite column. MM-oxidase activity was measured with the formaldehyde dehydrogenase-coupled assay; sulphide oxidizing activity by following the rate of sulphide disappearance at $254 \mathrm{~nm} .100 \%$ activity represents $2287 \mathrm{nmol} \mathrm{min} \mathrm{m}^{-1}\left(\mathrm{mg}^{2}\right.$ protein $)^{-1}$ for MM-oxidase and $745 \mathrm{nmol} \mathrm{min}^{-1}(\mathrm{mg} \text { protein })^{-1}$ for the sulphide-oxidizing activity.

possibility the purification procedure was repeated and the fractions from the two purification steps were now also tested for sulphide-oxidizing activity. Indeed, a sulphide-oxidizing capacity (with a specific activity of about $1.4 \mu \mathrm{mol} \mathrm{S}^{2-} \min ^{-1}(\mathrm{mg} \text { protein) })^{-1}$ measured at $30 \mu \mathrm{M}$ sulphide) with a $\mathrm{pH}$ optimum of 7.5 was copurified with MM-oxidase. However, the final yield $(95 \%)$ and purification ratio (40), determined by sulphide-dependent $\mathrm{O}_{2}$ consumption or sulphide disappearance (measured according to the method of Trüper \& Schlegel, 1964), were dissimilar to those for MM-oxidase (Table 1), and the ratio of the MM and sulphide oxidation rates in the different fractions from the hydroxylapatite column was not constant (a deviation of about $35 \%$ was found). This raised the question of whether the two activities were due to one enzyme.

Upon heat denaturation at $59^{\circ} \mathrm{C}$ (Fig. 3), both enzyme activities disappeared at an equal rate, whereas they were both unaffected by heating for $10 \mathrm{~min}$ at $50{ }^{\circ} \mathrm{C}$ and completely destroyed after heating for $10 \mathrm{~min}$ at $65^{\circ} \mathrm{C}$, which would be consistent with the involvement of only one enzyme. For a further assessment of its purity the enzyme preparation was applied to gel permeation HPLC with dual wavelength detection, a technique described by Frank et al. (1985); this detects inhomogeneities in chromatographic peaks via determination of the ratio of two absorbances. Since the ratio is specific for a particular protein, deviations in it are indicative of impurities. Only the peak fraction from the hydroxylapatite column appeared to be effectively 

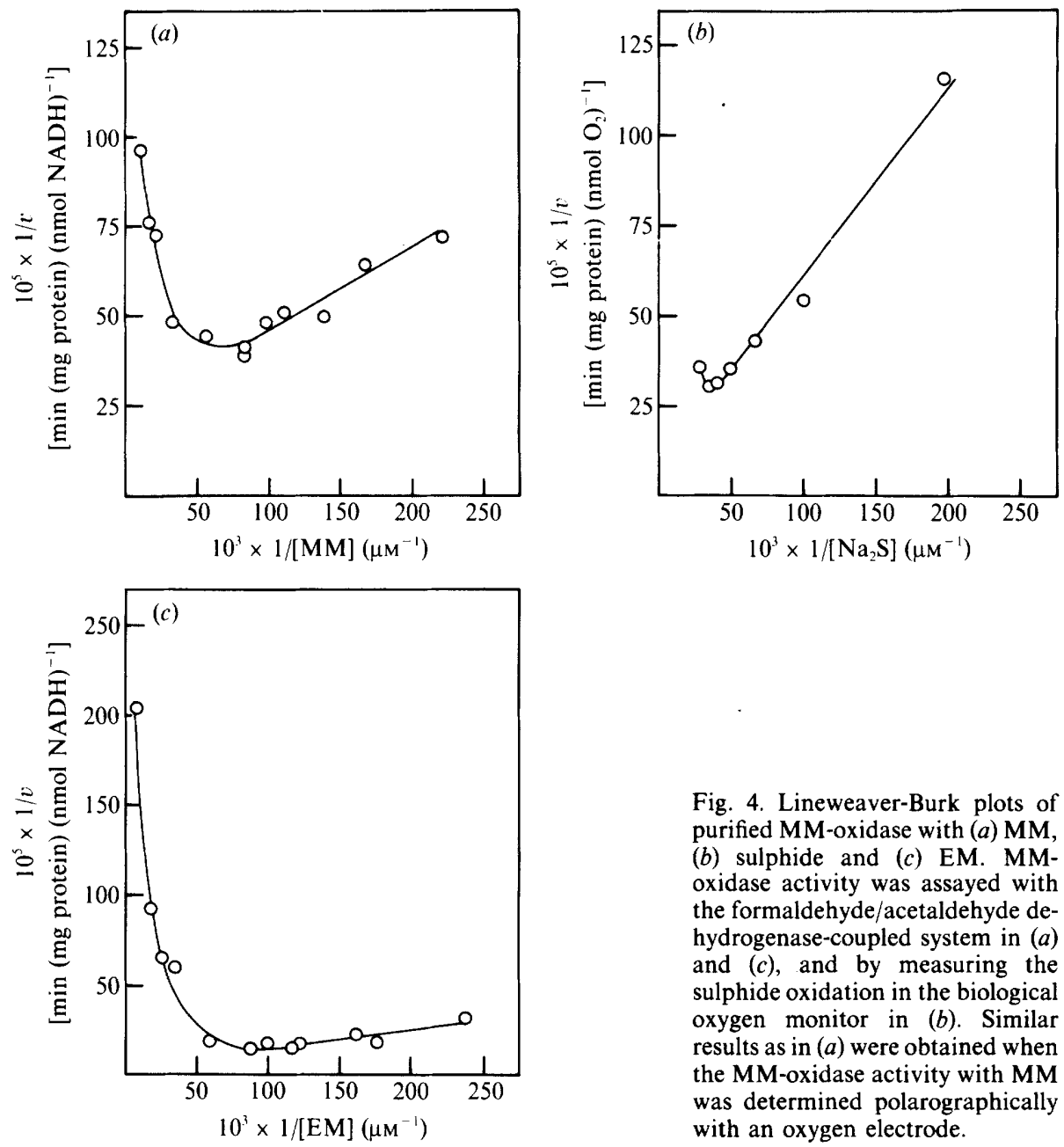

Fig. 4. Lineweaver-Burk plots of purified MM-oxidase with (a) MM, (b) sulphide and (c) EM. MMoxidase activity was assayed with the formaldehyde/acetaldehyde dehydrogenase-coupled system in (a) and $(c)$, and by measuring the sulphide oxidation in the biological oxygen monitor in (b). Similar results as in $(a)$ were obtained when the MM-oxidase activity with MM was determined polarographically with an oxygen electrode.

homogeneous with an $A_{280}: A_{205}$ of $0.05406 \pm 0.00020$ and a relative standard deviation of $0.4 \%$, whereas the others showed significant impurities (ratios of e.g. $0.05421 \pm 0.00080$ and a relative standard deviation of $1.5 \%$ were found). Since the peak fraction also oxidized sulphide it was concluded that this activity was likely to be due to MM-oxidase. It therefore, seemed probable that sulphide oxidation by this preparation was according to equation 2 :

$$
\mathrm{H}_{2} \mathrm{~S}+\mathrm{O}_{2} \rightarrow \mathrm{S}^{0}+\mathrm{H}_{2} \mathrm{O}_{2}
$$

Several tests were performed to establish the stoicheiometry of this reaction. The assay method of Ngo \& Lenhoff (1980) showed that sulphide oxidation was coupled with $\mathrm{H}_{2} \mathrm{O}_{2}$ formation. Furthermore, $\mathrm{O}_{2}$ was utilized upon sulphide oxidation, although the amount used varied in the various fractions. The expected reaction product, elemental sulphur, was not detected (see Methods) and the stoicheiometry needs to be further established.

\section{Substrate specificity of $M M$-oxidase and effect of inhibitors}

The specificity for electron donors of the purified enzyme and its sensitivity to several inhibitors is shown in Table 2. The three substrates with which MM-oxidase showed substantial activity were also potent inhibitors as is clear from the double reciprocal Lineweaver-Burk plots in Fig. 4, from which $K_{\mathrm{m}}$ values of $10 \mu \mathrm{M}$ for $\mathrm{MM}, 60 \mu \mathrm{M}$ for $\mathrm{Na}_{2} \mathrm{~S}$ and $18 \mu \mathrm{M}$ for EM were 
Table 2. Substrate specificity of $M M$-oxidase and its sensitivity towards known enzyme inhibitors

The effect of potential inhibitors was tested by determining the rate of formaldehyde formation at a fixed MM concentration by the Nash (1953) method after a period of $2 \mathrm{~min}$ in the presence and absence of varying concentrations of inhibitors. The reaction was stopped by the addition of $0.65 \%(\mathrm{w} / \mathrm{v})$ perchloric acid. Alternatively, the effect of the various compounds was tested on the rate of $\mathrm{O}_{2}$ uptake or formaldehyde formation in the formaldehyde dehydrogenase coupled assay. Compounds tested as
substrate

Methyl mercaptan

Ethyl mercaptan

Sulphide

Mercaptoethanol

Methanol

Methylamine

Methyl chloride

Methyl bromide

Sodium methane

sulphonate

Dimethyl sulphide

Thiosulphate

Sulphite

Elemental sulphur

Substrate Inh
+
+
+
-
-
-
-
-
-
-
-
-

Concn*
$14 \mu \mathrm{M}$
$11 \mu \mathrm{M}$
$27 \mu \mathrm{M}$
$15 \mu \mathrm{M}$
$1 \mathrm{mM}$
$0.2 \mathrm{mM}$
$1 \mathrm{mM}$
$1 \mathrm{mM}$
$1 \mathrm{mM}$
$1 \mathrm{mM}$
$1 \mathrm{mM}$
$1 \mathrm{mM}$
$0.5 \mathrm{mM}$

$+\quad 0.2 \mathrm{mM}$

$-\quad 1 \mathrm{~mm}$

$-\quad 1 \mathrm{~mm}$

$-\quad 1 \mathrm{~mm}$

$-\quad 1 \mathrm{mM}$

$-\quad 1 \mathrm{~mm}$

$\begin{array}{ll}- & 1 \mathrm{mM} \\ - & 0.5 \mathrm{mM}\end{array}$

\section{Enzyme inhibitors}

$$
\text { tested }
$$

Ammonium sulphate

Ammonium chloride

Sodium sulphate

Cyanide

EDTA

Neocuproine

Inhibition

Concn*

$+\quad 0.3 \mathrm{~mm}$

$+\quad 0.3 \mathrm{~mm}$

- $1 \mathrm{mM}$

$+\quad 10 \mu \mathrm{M}$

- $\quad 0.3 \mathrm{mM}$

* Threshold concentration at which inhibition was observed or the maximum concentration tested at which no inhibition was observed.

calculated. The $K_{\mathrm{i}}$ value for MM, calculated from a Dixon plot (Dixon, $1953 ; 1 / v$ against inhibitor concentration), for the inhibitory part of Figure $4(a)$ was $42 \mu \mathrm{M}$.

MM-oxidase showed no activity with methyl chloride and methyl bromide, so a different enzyme must be responsible for the dechlorination of methyl chloride during growth of Hyphomicrobium $\mathrm{MC1}$ on this compound (Hartmans et al., 1986).

Inhibition of MM-oxidase activity by sulphide, methylamine and cyanide was further investigated. When the data were plotted according to Cornish-Bowden (1974) (see also Methods) all three compounds proved to be non-competitive inhibitors of the enzyme. The $K_{\mathrm{i}}$ values found were: $90 \mu \mathrm{M}$ for sulphide, $1.4 \mathrm{mM}$ for methylamine and $40 \mu \mathrm{M}$ for cyanide. The $K_{\mathrm{m}}$ for MM calculated from the Cornish-Bowden plot of the inhibition of MM-oxidase with sulphide was $5 \mu \mathrm{M}$.

In order to investigate further whether MM and sulphide oxidation were due to one enzyme, the effect of two inhibitors on both activities was compared. At approximately $5 \mu \mathrm{M}$ mercaptoethanol, $50 \%$ inhibition of sulphide oxidation was found, whereas the same extent of inhibition of $\mathrm{MM}$ oxidation was found at $40 \mu \mathrm{M}$. $\mathrm{NH}_{4}^{+}$, which proved to be inhibitory to $\mathrm{MM}$ oxidase, caused about $70 \%$ inhibition of both activities at approximately $4 \mathrm{~mm}$.

\section{MM oxidation by alcohol oxidase from $H$. polymorpha}

The involvement of an oxidase in the metabolism of methylated sulphides is not unique. Oxidases have also been encountered in the metabolism of methylated amines by Arthrobacter spp. and in the metabolism of methanol by yeasts (Anthony, 1982). Methylamine oxidase resembles $\mathrm{MM}$-oxidase in its high degree of substrate specificity: it only oxidizes amines, whereas MM-oxidase is only active with thiols. Furthermore, both enzymes are unable to oxidize alcohols. Unlike these oxidases, alcohol oxidase (EC 1.1.3.13) seems to be less substrate specific. Previously, EM has been reported to be a substrate for yeast alcohol oxidase (Hopkins, 1985). This raised the question of whether this enzyme would also catalyse MM oxidation. Alcohol oxidase, partially purified from H. polymorpha as described by Verduyn $e t$ al. (1984), oxidized MM with the concomitant production of formaldehyde, sulphide and hydrogen peroxide. The $K_{\mathrm{m}}$ and the $V_{\max }$ for MM (calculated from a Michaelis-Menten plot) appeared to be about $110 \mu \mathrm{M}$ and approximately $27 \mathrm{nmol} \mathrm{m^{-1 }}(\mathrm{mg} \text { protein })^{-1}$ respectively. $\mathrm{MM}$ in 
concentrations up to $500 \mu \mathrm{M}$ was not inhibitory to the enzyme. In contrast to the MM-oxidase preparation, alcohol oxidase did not oxidize sulphide. This suggested that the catalytic mechanism for MM oxidation by alcohol oxidase may be different from that of hyphomicrobial MM-oxidase.

\section{DISCUSSION}

MM-oxidase, purified from crude cell-free extracts of Hyphomicrobium EG grown on DMSO at a $D$ value of $0 \cdot 018 \mathrm{~h}^{-1}$, comprises $8-10 \%$ of the total cellular protein (Table 1). Since the specific activity of the enzyme is similar in crude extracts of DMS-grown cells (Suylen et al., 1986), these are likely to contain comparable levels. The $M_{\mathrm{r}}$ of MM-oxidase under denaturing conditions (49000) is comparable to that found under native conditions (40000-50000), indicating the enzyme to be a monomer. Since the spectrum showed no absorbance in the visible region, the enzyme preparation is not likely to contain cytochromes or flavin. The insensitivity of MM-oxidase towards the metal-chelating agents EDTA and neocuproine suggests that metal ions are not involved in the functioning of the enzyme either and therefore the identity of its prosthetic group remains to be established.

The purified MM-oxidase also oxidized sulphide. The fact that (i) both HPLC and SDSPAGE suggest that the enzyme preparation is almost pure, (ii) the heat inactivation curve (Fig. 3) of the two activities is very similar, (iii) $\mathrm{H}_{2} \mathrm{O}_{2}$ is formed in both reactions and (iv) the activities are sensitive to the same inhibitors, is consistent with the conclusion that sulphide and MM oxidation are due to one enzyme. However, the fact that the MM and sulphide oxidative capacities were present in different ratios in the various fractions from the hydroxylapatite column seems to contradict this and therefore the data presented here do not fully exclude the existence of two very similar enzymes responsible for the separate activities and influenced in their action by each other's substrate.

Hyphomicrobium EG has been shown to be able to derive energy from the oxidation of sulphide (Suylen et al., 1986). The oxidation of sulphide by MM-oxidase is not likely to yield energy since, by lack of electron transport, it would not allow the build-up of an electrochemical gradient (pmf). If elemental sulphur were the initial product of sulphide oxidation the subsequent oxidation to sulphuric acid might yield energy. Alternatively, Hyphomicrobium EG might have another sulphide-oxidizing enzyme, responsible for sulphide oxidation in vivo. At first sight it seemed unlikely that Hyphomicrobium EG contains two sulphide-oxidizing enzymes, and the question arose as to how much the available MM-oxidase might be able to contribute to the sulphide oxidation by whole cells. This could be estimated by comparing the affinity $\left(V_{\max } / K_{\mathrm{s}}\right.$ ) for sulphide of whole cells with that of the purified enzyme. The $V_{\max }$ and $K_{\mathrm{s}}$ values for sulphide of whole cells were $816 \mathrm{nmol} \mathrm{O}_{2} \min ^{-1}$ (mg protein) $)^{-1}$ and $17 \mu \mathrm{M}$ respectively (G. M. H. Suylen, unpublished data), giving an affinity of 48. The $V_{\max }$ and $K_{\mathrm{s}}$ values of the purified enzyme were $11556 \mathrm{nmol} \mathrm{O}_{2} \mathrm{~min}^{-1}(\mathrm{mg} \text { protein) })^{-1}$ and $60 \mu \mathrm{M}$ respectively. When it is taken into account that $8-10 \%$ of the total protein is MM-oxidase, the $V_{\max }$ of the total enzyme in the cells would be $1155 \mathrm{nmol} \mathrm{O}_{2} \mathrm{~min}^{-1}(\mathrm{mg} \text { protein) })^{-1}$, giving a $V_{\max } / K_{\mathrm{s}}$ of 19 . Thus the sulphideoxidizing activity of MM-oxidase could substantially contribute to the total turnover of sulphide, though it cannot be excluded that a second sulphide-oxidizing enzyme is present in Hyphomicrobium EG.

When Hyphomicrobium EG is growing on DMSO at a $D$ value of $0.018 \mathrm{~h}^{-1}$ it should be able to

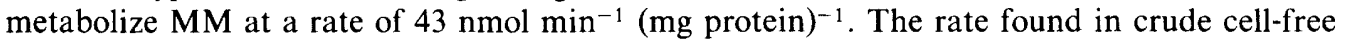

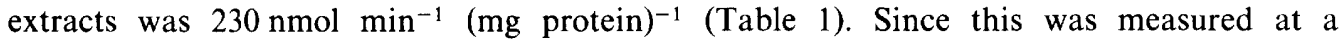
concentration of $\mathrm{MM}$ of about $100 \mu \mathrm{M}$, the 'true' (uninhibited) rate is likely to be a factor of 4.5 higher (cf. Fig. $4 a$ ). So the enzyme is present in these cells at a level which seems to be in a 24fold excess of what is expected to be necessary. Data of potential MM oxidation rates at $D$ values of $0.01,0.02$ and $0.035 \mathrm{~h}^{-1}$ (Suylen et al., 1986) corrected in a similar way as above indicated a 41-, 9- and 4-fold excess respectively. The dramatic increase of MM-oxidase at the lower $D$ values suggests that $\mathrm{MM}$-oxidase is the bottle-neck enzyme of the metabolic pathway and that the organism is increasing its affinity for the growth-limiting substrate at these $D$ values. 
Alternatively, it may show that the organism increases its oxidase concentration to keep $\mathrm{MM}$ at a low, non-toxic concentration, but that the maintenance of the high MM-oxidase level requires an energy input which the organism can no longer afford at the higher $D$ values, leaving it more vulnerable to the toxic MM.

The authors would like to thank Mr. E. Dakkenhorst for technical assistance, Dr J. Frank Jzn for doing the gel permeation HPLC measurements and Dr G. W. Haywood for determining the $M_{\mathrm{r}}$ of the enzyme. P. J. Large thanks the Scientific Affairs Division of NATO (Brussels) for a Senior Scientist Award, and the Science and Engineering Research Council (Swindon) for additional financial support.

\section{REFERENCES}

ANTHONY, C. (1982). The Biochemistry of Methylotrophs. New York \& London: Academic Press.

de Bont, J. A. M., van Dijken, J. P. \& Harder, W. (1981). Dimethyl sulphoxide and dimethyl sulphide as a carbon, sulphur and energy source for growth of Hyphomicrobium S. Journal of General Microbiology 127, 315-323.

BRADFORD, M. M. (1976). A rapid and sensitive method for the quantitation of microgram quantities of protein utilizing the principle of protein-dye binding. Analytical Biochemistry 72, 248-254.

Cohen, G. \& Somerson, N. L. (1969). Catalaseaminotriazole method for measuring secretion of hydrogen peroxide by microorganisms. Journal of Bacteriology 98, 543-546.

CORNISH-BOWDEN, A. (1974). A simple graphical method for determining the inhibition constants of mixed, uncompetitive and non-competitive inhibitors. Biochemical Journal 137, 143-144.

Dixon, M. (1953). The determination of enzyme inhibitor constants. Biochemical Journal 55, 170-171.

Frank, J. JZN, Duine, J. A., Billiet, H. A. H., Drouen, A. C. J. H., DE Galan, L., Vandeginste, B. G. M. \& Essens, R. (1985). Data treatment in multi-wavelength detection in HPLC of biochemical compounds. Fresenius' Zeitschrift für analytische Chemie 322, 761-765.

Hartmans, S., Schmuckle, A., Cook, A. M. \& LEISINGER, T. (1986). Methyl chloride: naturally occurring toxicant and C-1 growth substrate. Journal of General Microbiology 132, 1139-1142.

Haywood, G. W. \& LaRge, P. J. (1981). Microbial oxidation of amines. Distribution, purification and properties of two primary-amine oxidases from the yeast Candida boidinii grown on amines as sole nitrogen source. Biochemical Journal 199, 187-201.

Hopkins, T. R. (1985). A multipurpose enzyme sensor based on alcohol oxidase. American Biotechnological Laboratory 3, 32-35.

Kato, N., Tamaoki, T., TAni, Y. \& Ogata, K. (1972). Purification and characterization of formaldehyde dehydrogenase in a methanol-utilizing yeast, Kloeckera sp. no. 2201. Agricultural and Biological Chemistry 36, 2411-2419.
Kuwata, K., Uebori, M., Yamada, K. \& YamazaKi, Y. (1982). Liquid chromatographic determination of alkylthiols via derivatization with 5,5'-dithiobis(2nitrobenzoic acid). Analytical Chemistry 54, 10821087.

NASH, T. (1953). The colorimetric estimation of formaldehyde by means of the Hantzsch reaction. Biochemical Journal 55, 416-421.

NGo, T. T. \& Lenhoff, H. M. (1980). A sensitive and versatile chromogenic assay for peroxidase and peroxidase-coupled reactions. Analytical Biochemistry 105, 389-397.

PASZCZYNSKI, A., HUYNH, V.-B. \& CRAWford, R. (1985). Enzymatic activities of an extracellular, manganese-dependent peroxidase from Phanerochaete chrysosporium. FEMS Microbiology Letters 29. 37-41.

Saunders, B. C., Holmes-Siedle, A. G. \& Stark, B. P. (1964). Peroxidase. London: Butterworth.

SörBo, B. H. (1957). A colorimetric method for the determination of thiosulphate. Biochimica et biophysica acta 23, 412-417.

Suylen, G. M. H. \& Kuenen, J. G. (1986). Chemostat enrichment and isolation of Hyphomicrobium EG, a dimethyl sulphide oxidizing methylotroph and reevaluation of Thiobacillus MS1. Antonie van Leeuwenhoek 52, 281-293.

Suylen, G. M. H., Stefess, G. C. \& Kuenen, J. G. (1986). Chemolithotrophic potential of a Hyphomicrobium species, capable of growth on methylated sulphur compounds. Archives of Microbiology 146, 192-198.

TrüPer, H. G. \& SCHLEgel, H. G. (1964). Sulphur metabolism in Thiorhodaceae. 1: Quantitative measurements on growing cells of Chromatium okenii. Antonie van Leeuwenhoek 30, 225-238.

Verduyn, C., van DiJken, J. P. \& Scheffers, W. A. (1984). Colorimetric alcohol assays with alcohol oxidase. Journal of Microbiological Methods 2, 15-25.

WEBER, K. \& OSBORN, M. (1969). The reliability of molecular weight determinations by sodium dodecylsulphate polyacrylamide gel electrophoresis. Journal of Biological Chemistry 244, 4406-4412. 